\title{
The Effect of the Blue and Black Light Trap on the Diversity of the Trichoptera (Caddisfly Adult) and Other Insects in Lotic and Lentic Area of Mae Tam Reservoir, Thailand
}

\author{
Arthit Nuntakwang ${ }^{1, *}$, Decha Thapanya ${ }^{2}$ and Hakan Bozdoğan ${ }^{3}$ \\ ${ }^{I}$ Department of Biology, School of Science, University of Phayao, Phayao 50200, Thailand \\ ${ }^{2}$ Department of Biology, Faculty of Science, Chiang Mai University, Chiang Mai 51000, Thailand \\ ${ }^{3}$ Department of Plant and Animal Production, Vocational School of Technical Sciences, \\ University of Kirşehir Ahi Evran 40100, Turkey
}

('Corresponding author's e-mail: natsuyazumi@gmail.com)

Received: 16 July 2020, Revised: 20 May 2021, Accepted: 10 June 2021

\begin{abstract}
This study was conducted using two types of light traps to collect the insects at Mae Tam Reservoir from January to April 2018. The sampling area was divided into 4 points. Two points were located at the reservoir's bank, and the others were located at the reservoir's outlet. The study aimed to compare the efficiency of the fluorescent tube's blue and purple light, which had a different wavelength on insect's attraction. To compare the diversity of Trichoptera in the different stream habitats, Sørensen similarity index, Shannon-Wiener index, and Evenness index were used. The result showed that purple light could attract insects better than blue light. Hymenoptera was attracted by purple light. Coleoptera and Hemiptera were attracted by blue light. The study on the diversity of Trichoptera showed that there were 2,534 individuals of 9 families 48 species were collected. Ecnomus puro was the most abundant species $(1,120$ individuals). The highest Shannon-Wiener diversity index was sampling points 4 (2.10). The highest Evenness index was sampling points 4 (0.62). Sørensen similarity index showed that sampling points 3 and 4 had the highest value $(67.92 \%)$ because they were adapted from a natural creek to concrete where boulder, gravel, cobble, sand, and woody material were deposited at the stream bottom. These provided various microhabitats for insect larva to live and develop. The riparian had affected the distribution and colonization of mature insects.
\end{abstract}

Keywords: Trichoptera, Fluorescent tube, Light trap, Lentic ecosystem, Reservoir

\section{Introduction}

Light is an ecological factor that affected the biological process of insects. Flying and migration behavior depend on illuminance, photoperiod, wavelength, direction, and degree of polarization. Many insects fly to the light at night due to their inherited behavior which benefits movement, foraging, and mating. The light trap was invented for any purpose, such as investigating agricultural insects, trapping eatable insects, and some nocturnal insects [1]. The light trap was used widely in Thailand. Most of the insect responds to the wavelength between $253-700 \mathrm{~nm}$. A different wavelength can attract more than 1,000 species of nocturnal insects. Moths and some insects were attracted by a short wavelength $(>400$ $\mathrm{nm}$.) that nearly with the ultraviolet wavelength $(300-380 \mathrm{~nm}$.) [2]. Then, blue fluorescent light and purple fluorescent light are widely sold and used for trapping insects but the study on their specification is not quite clear.

Taxonomy and diversity of Trichoptera in Thailand were studied for many decades, especially in Northern Thailand [3-28]. Most of the research on Trichopteran was conducted in the lotic ecosystem where it has more species than a lentic ecosystem [29]. Microhabitat (especially a variation on stream bottom) has affected the habit of caddisfly larvae. Early instars of caddisflies live in water; adults are found on the bank of a stream or river where larva live [30]. 


\section{Materials and methods}

Sampling location and sampling point selection

Mae Tam reservoir is located at Phayao province in the north of Thailand (Figure 1). This reservoir receives water from the Mae Tum watershed used for agriculture. The ridge length of the reservoir is approximately $1.8 \mathrm{~km}$. Water storage is $37,000,000 \mathrm{~m}^{3}$. The outlet transfers water to an irrigation channel in which the channel bottom was modified to a concrete bed. The spillway drains the excess water into the irrigation channel during the wet season. Some materials such as a boulder, cobble, gravel, sand and woody material that flow via water current, were stored in a channel. This condition is similar to lotic stream during the wet season and lentic stream in the dry season (Ecotone ecosystem). Four sampling points in the Mae Tum reservoir were chosen to place a light trap overnight. These sampling points include lentic and lotic habitat. Sampling points 1, 2 were located at the reservoir bank (represent as lentic habitat) and sampling points 3, 4 were located at the channel (represent as lotic habitat) (Figure 2). Each sampling point must not be disturbed by the other light sources. The coordinates and elevation of each sampling point are shown in Table 1.

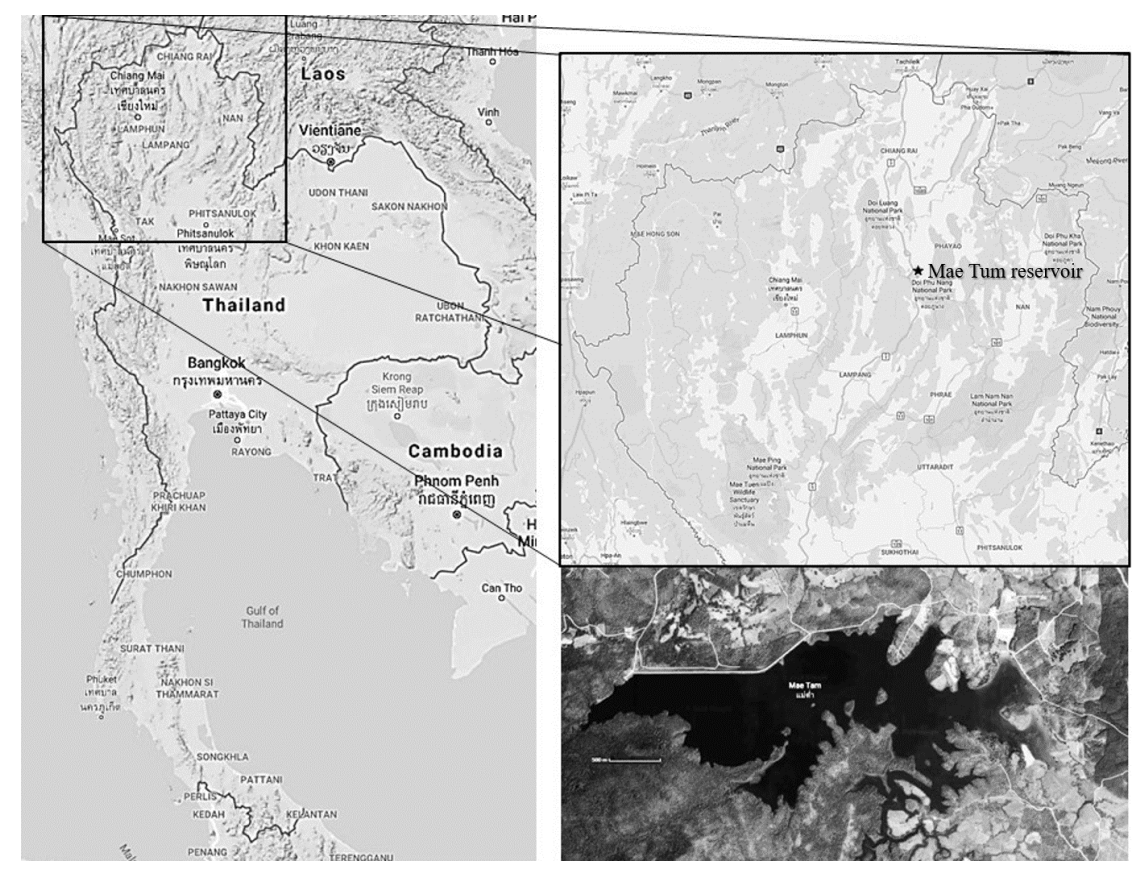

Figure 1 Mae Tum Reservoir, Phayao Province, Northern of Thailand.

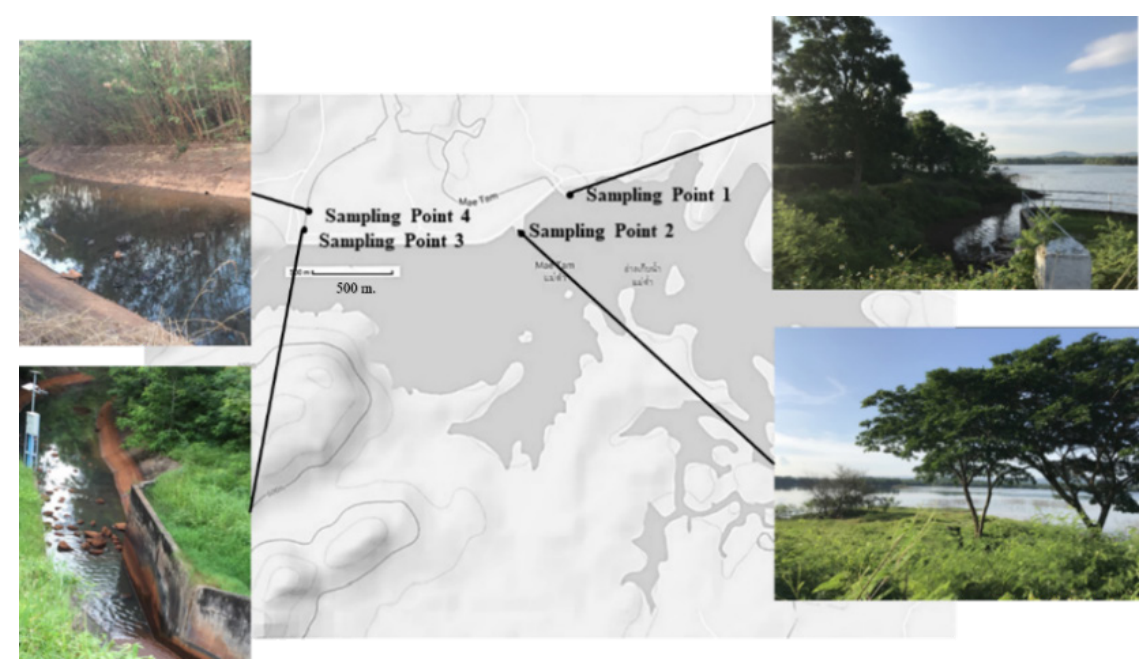

Figure 2 Four sampling points at Mae Tum reservoir. 
Table 1 Coordination and elevation of each sampling points.

\begin{tabular}{cccc}
\hline Sampling point & Location / habitat & Coordinate & Elevation (m.asl.) \\
\hline 1 & Reservoir bank / lentic & $19^{\circ} 0^{\prime} 28^{\prime \prime} \mathrm{N}, 99^{\circ} 57^{\prime} 27^{\prime \prime} \mathrm{E}$ & 470 \\
2 & Reservoir bank / lentic & $19^{\circ} 0^{\prime} 22^{\prime \prime} \mathrm{N}, 99^{\circ} 57^{\prime} 18^{\prime \prime} \mathrm{E}$ & 450 \\
3 & Channel / lotic & $19^{\circ} 0^{\prime} 18^{\prime \prime} \mathrm{N}, 99^{\circ} 56^{\prime} 33^{\prime \prime} \mathrm{E}$ & 440 \\
4 & Channel / lotic & $19^{\circ} 0^{\prime} 24^{\prime \prime} \mathrm{N}, 99^{\circ} 56^{\prime} 33^{\prime \prime} \mathrm{E}$ & 440 \\
\hline
\end{tabular}

\section{Light trap setting and insect collecting}

The light trap set consists of 1) $18 \mathrm{~W}$ blue and black light fluorescent tubes 2) battery DC 12V 11Ah 3) plastic tray with mixture of water and detergent. The blue and black light fluorescent tubes were measured as a wavelength using a direct spectroscope (Figure 3). Light traps were left overnight (from dusk until dawn) to collect the insects at each sampling point (Figure 4). Light traps were placed away from electric light. Each light trap had a distance of more than 200 meters to avoid light disturbance on insect attraction. On the morning of the next day, the material for insects was transferred into $80 \%$ ethyl alcohol and transported to the laboratory. The sampling was conducted twice a week from January to April 2018.

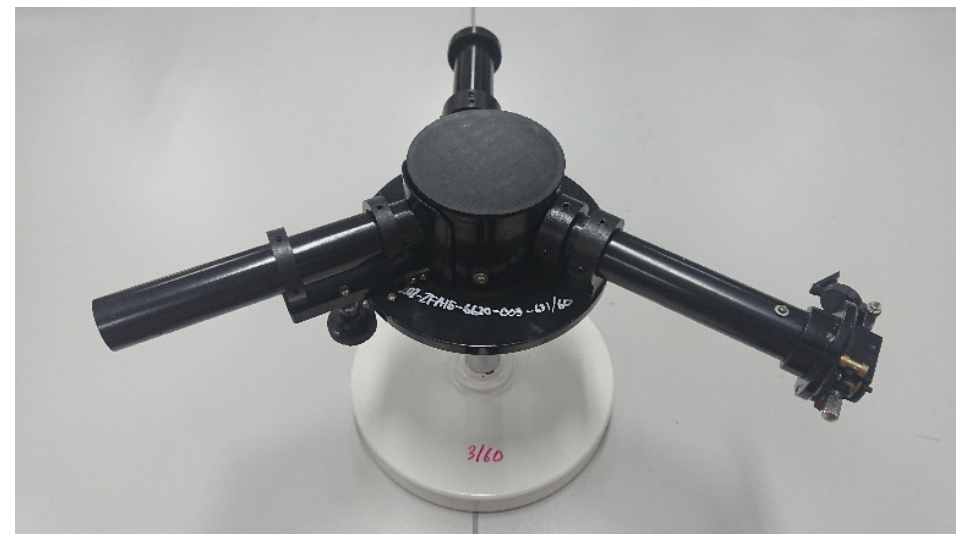

Figure 3 Direct spectroscope.

\section{Sorting and identification}

Trichoptera were separated from another insect sample. Trichoptera (male) were sorted and examined under a dissecting stereomicroscope. The last 2 abdominal segments of adult male genitalia were separated and cleared by heating in $10 \% \mathrm{NaOH}$ at $70{ }^{\circ} \mathrm{C}$ for $30-45 \mathrm{~min}$ (depend on sample size). Species-level identification was done by using the atlas of southeast Asian Trichoptera [31] and Trichoptera world checklist [32]. Other insect groups were identified to order. 


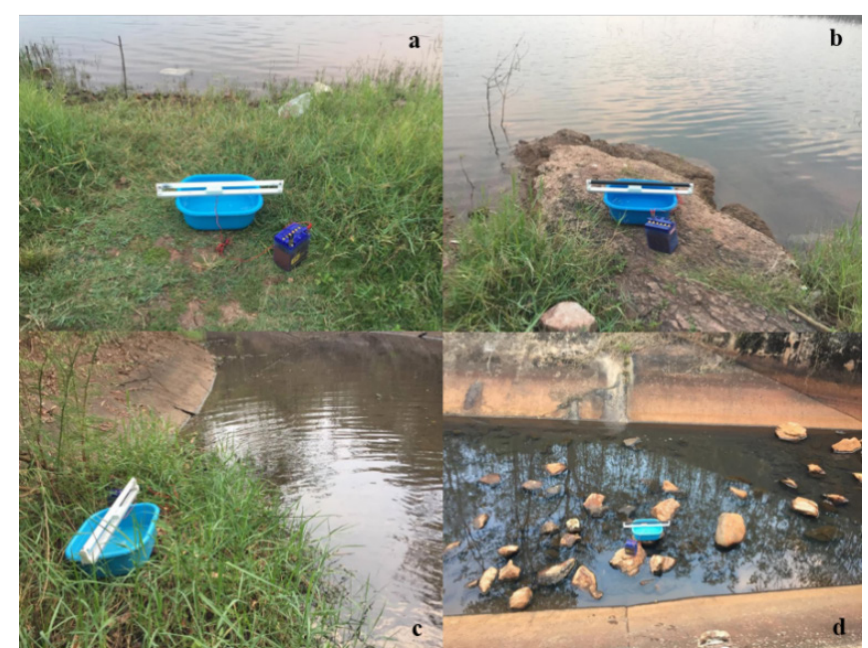

Figure 4 (a) - (b) Blue and black light traps at sampling point 1 and 2, (c) - (d) 3 and 4.

\section{Data analysis and statistical analysis}

Trichoptera species and other insect orders were count and summarized. Sørensen similarity index [33] was used to compare a Trichoptera species in each sampling point.

$\mathrm{C}_{\mathrm{s}}=[2 \mathrm{j} /(\mathrm{a}+\mathrm{b})] \times 100$

where $\quad \mathrm{C}_{\mathrm{s}}=$ Percentage of Sørensen index (Sørensen's similarity coefficient)

$\mathrm{j}=$ Number of species found in both sites

$\mathrm{a}=$ Number of species in site $\mathrm{A}$

$b=$ Number of species in site B

Shannon - Wiener diversity index and Species evenness [30] were chosen to describe species diversity in each sampling point.

$H^{\prime}=-\sum_{i=1}^{s} p i \ln p i$

where $\quad H^{\prime}=$ Shannon - Wiener diversity index

$\mathrm{s}=$ Total of species

$\mathrm{pi}=$ Proportion of each species per total of species

$\mathrm{i}=$ species $1,2,3, \ldots, \mathrm{N}$

$J^{\prime}=H^{\prime} / \ln S$

where

$J^{\prime}=$ Species evenness index

$H^{\prime}=$ Shannon - Wiener diversity index

$S=$ Total of species in each sampling point

Independent-Sample t-test was used to compare species number of caddisfly species and other insect orders.

\section{Result and discussion}

By using a spectroscope, it was found that the blue light fluorescence had a wavelength of 405, 438, $548,580,625$ and $630 \mathrm{~nm}$, respectively, while the black light fluorescence had a wavelength of $375 \mathrm{~nm}$ (Table 2). The blue light fluorescence tubes gave more spectrum than the black light fluorescence tubes. A differentiation of the light came from a chemical substance inside a fluorescence tube. The blue light fluorescence tube contained magnesium tungstate which gave a white-blue light.The blacklight fluorescence contained cadmium borate and calcium tungstate (pink and blue light) that gave a purple light $[34,35]$. 
Table 2 The wavelength and the spectrum of the blue light fluorescence tube and the purple light fluorescence tube.

\begin{tabular}{cccc}
\hline \multicolumn{2}{c}{ Blue light fluorescence tube $(\boldsymbol{n}=\mathbf{5})$} & \multicolumn{2}{c}{ Black light fluorescence tube $(\boldsymbol{n}=\mathbf{5})$} \\
\hline Wavelength $(\mathbf{n m})$ & Spectrum & Wavelength $(\mathbf{n m})$ & Spectrum \\
\hline 405 & violet & 375 & Violet \\
438 & purple & - & - \\
548 & green & - & - \\
580 & yellow & - & - \\
625 & orange & - & - \\
630 & red & - & - \\
\hline
\end{tabular}

Forty-seven species of Trichoptera were collected. There were 12 species were found in lentic habitat and 18 species were found in lotic habitat. The others were found in both habitats (Table 3). Cheumatopsyche lucida (Hydropsychidae) and Ecnomus puro (Ecnomidae) were dominant species in the Mae Tum reservoir as they were found both in lentic and lotic habitats. According to Prommi et al. [36], these two species were also found in the Mae $\mathrm{Ku}$ stream at Tak province. These larvae had a good adaptation to live in various streams bottom. Cheumatopsyche copia, Potamyia alleni, Cheumatopsyche schwendingeri, Potamyia euadne, P. phaidra, Ecnomus alkaios, Oecetis bengalica, O. meghadouta, O. kodros, Setodes argentiguttatus, S. sarapis, Setodes tejasvin, S. okyrrhoe, Leptocerus posticus, Psychomyia kalais, P. lak, Abaria guatila, Hydroptila sabit, Oxyethira bogambara, Ugandatrichia honga, Marilia sumatrana, Chimarra toga, $C$. chiangmaiensis, $C$. terramater and $C$. monorum were very rare in this area. Luadee and Prommi [37] found these species in Tapee river, Surathanee province, and Mae Ku stream, Tak province. It can be concluded that these species were widespread in Thailand. However, their status and their species were rare.

Table 3 Species of Trichoptera and individual number in Mae Tum reservoir during January to April 2018.

\begin{tabular}{|c|c|c|c|c|c|}
\hline \multirow{2}{*}{ Family } & \multirow{2}{*}{ Species } & \multicolumn{4}{|c|}{ Sampling point } \\
\hline & & 1 & 2 & 3 & 4 \\
\hline \multirow[t]{6}{*}{ Hydropsychidae } & Cheumatopsyche lucida & 256 & 9 & 505 & 37 \\
\hline & Cheumatopsyche dhanikari $^{\text {(Lotic) }}$ & - & - & 5 & 3 \\
\hline & Cheumatopsyche copia ${ }^{(\text {Lentic })}$ & - & - & 1 & - \\
\hline & Cheumatopsyche globosa & - & 1 & 6 & 2 \\
\hline & Potamyia euadne $e^{(\text {Lentic })}$ & 1 & - & - & - \\
\hline & Potamyia phaidra ${ }^{(\text {Lotic })}$ & - & - & 1 & - \\
\hline \multirow[t]{5}{*}{ Ecnomidae } & Ecnomus puro & 366 & 462 & 207 & 85 \\
\hline & Ecnomus obtusus & 4 & 38 & 2 & 1 \\
\hline & Ecnomus cincibilus & - & 1 & 16 & 6 \\
\hline & Ecnomus jojachin ${ }^{\text {(Lotic) }}$ & - & - & 1 & 11 \\
\hline & Ecnomus singkarakensis ${ }^{\text {(Lotic) }}$ & - & - & 5 & - \\
\hline \multirow[t]{2}{*}{ Leptoceridae } & Oecetis tripunctata & 1 & 1 & 8 & 1 \\
\hline & Oecetis scutulata & 6 & 1 & - & 4 \\
\hline
\end{tabular}




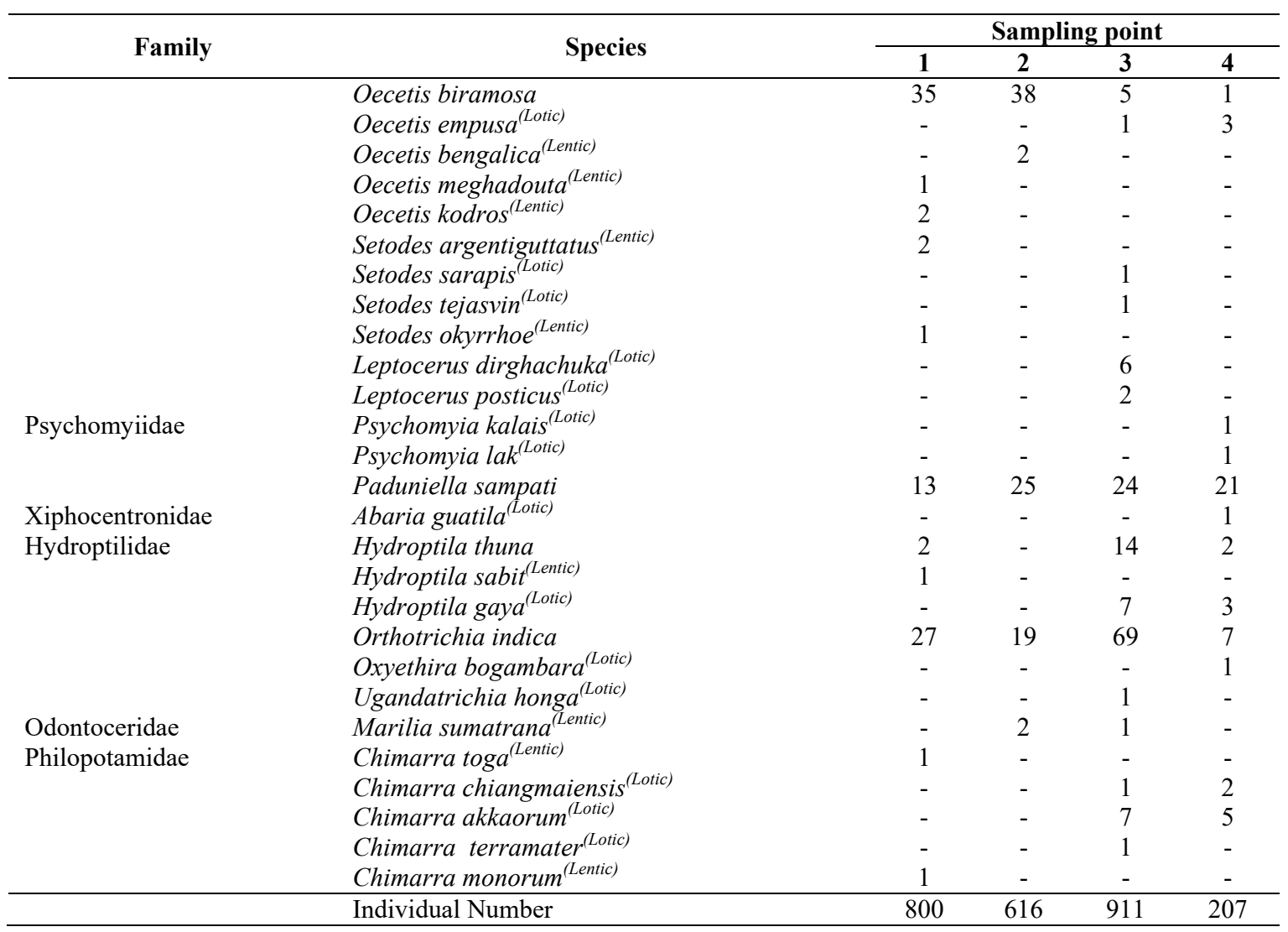

\section{Sørensen similarity index}

The sampling points 3 and 4 had the highest similarity of species $(67.91 \%)$, while the lowest similarity was sampling points 1 and $3(41.51 \%$ ) (Figure 4). The homogeneity of sampling point affects species abundance. The channel units of sampling point 3 were similar to run (smooth fast water) which was good to transport fine particulate organic matter (FPOM) during the wet season and store benthic particulate organic matter (BPOM) during the dry season [38]. The channel bed of sampling 4 had boulders, rocks, cobbles, gravel, and depositional pool which provide various habitats and food resources for the larva stage $[39,40]$.

\begin{tabular}{|c|c|c|c|c|}
\hline \multicolumn{5}{|l}{ Similarity $>70 \%$} \\
\hline$\bullet$ & \multicolumn{3}{l}{$\begin{array}{l}\text { Similarity }=70-50 \% \\
\text { Similarity }<50 \%\end{array}$} \\
\hline Sampling point & $\mathbf{1}$ & $\mathbf{2}$ & $\mathbf{3}$ & $\mathbf{4}$ \\
\hline $\mathbf{1}$ & & 52.63 & 41.51 & 49.83 \\
\hline $\mathbf{2}$ & $\bullet$ & & 53.33 & 57.89 \\
\hline $\mathbf{3}$ & & $\bullet$ & & 67.92 \\
\hline $\mathbf{4}$ & & $\bullet$ & $\bullet$ & \\
\hline
\end{tabular}

Figure 4 Sørensen similarity index of Trichoptera species between 4 sampling points. 


\section{Shannon-wiener diversity index}

The sampling point 4 had the highest value (2.10), while the sampling point 1,3 and 2 were 1.57 , 1.54 and 1.06, respectively. Although the sampling point 3 was lotic habitat as in sampling point 4 , the channel bed was sand and concrete. Furthermore, sampling point 4 had mixed materials. Sampling points 1 and 3 had a similar value because they were "ecotone" where a lentic and lotic habitat closed together. Trichoptera adults can share a micro habitat for foraging, mating, and lay eggs between these 2 habitats. Cheumatopsyche lucida, Ecnomus puro, Ecnomus obtusus, Ecnomus alkmene, Oecetis tripunctata, Oecetis biramosa, Paduniella sampati and Orthotrichia indica were species in this study that reflected this evidence.

\section{Species evenness}

Sampling point 4 had the highest species evenness (0.67). Sampling point 2 had the lowest species evenness (0.39), while sampling points 1 and 3 were 0.50 and 0.45 . A low value reflects that species in sampling tended to have more changes on species composition if their habitat was disturbed. Cheumatopsyche copia, Potamyia phaidra, Ecnomus alkaios, Ecnomus singkarakensis, Oecetis bengalica, Oecetis bengalica, Leptocerus dirghachuka, Leptocerus posticus, Ugandatrichia honga, Marilia sumatrana, and Chimarra terramater, these species were reservoir-habitat sensitive. The reason was that they were rarely found only at sampling points 2 and 3.

Ephemeroptera and Diptera had the highest individual number in sampling points 1 and 2 (lenthic habitat), while Diptera and Trichoptera had the highest individual number in sampling points 3 and 4 (lotic habitat). Odonata, Orthoptera, Hemiptera, Collembola, and Isoptera were very few in this reservoir. Coleoptera and Hemiptera were attracted by blue light trap better than the black light trap. Trichoptera, Ephemeroptera, Odonata, Orthoptera, Diptera, Lepidoptera, Hymenoptera, Homoptera, Isoptera, and Collembola were attracted by the black light trap better than the blue light trap (Table 4). By using independent-samples t-test, there is no significant difference between these light traps on the individual number of insects $(p<0.05)$.

Ephemeroptera, Orthoptera, Coleoptera, Hymenoptera, and Isoptera were collected in lentic habitat (sampling point 1, 2) more than in lotic habitat (sampling point 3, 4). Trichoptera, Diptera, Hemiptera, Lepidoptera, Homoptera, and Collembola were collected in lotic habitat more than in lotic habitat. By using independent-samples t-test, there is no significant difference between the lentic and lotic habitats on an individual number of insects that were caught $(p<0.05)$. Considering the total of individual insect number $(44,175)$, sampling point 3 had the highest catch $(15,886)$ which consisted of Diptera $(543$ individuals from the blue light and 5,576 individuals from the black light), Trichoptera (1,356 individuals from the blue light and 3,675 individuals from the black light) and Ephemeroptera (352 individuals from the blue light and 2,131 individuals from the black light). The lowest catch was found in sampling point 4 which consisted of Diptera (2,101 individuals from the blue light and 1,313 individuals from the black light), Trichoptera (1,207 individuals from the blue light and 430 individuals from the black light) and Coleoptera (440 individuals from the blue light and 415 individuals from the black light). By using statistical analysis (One-way ANOVA), only Trichoptera had a significant difference between the sampling points $(p<0.05)$ 
Table 4 The insects were collected using the blue and black light traps in sampling points 1-4 from January. to April 2018.

\begin{tabular}{|c|c|c|c|c|c|c|c|c|c|c|c|c|c|}
\hline \multirow[b]{2}{*}{$\begin{array}{c}\text { Sampling } \\
\text { point }\end{array}$} & \multirow[b]{2}{*}{$\begin{array}{l}\text { Light } \\
\text { trap }\end{array}$} & \multicolumn{12}{|c|}{ Individual number of insect order } \\
\hline & & & $\begin{array}{l}\frac{T}{0} \\
\frac{0}{0} \\
\frac{0}{0} \\
\frac{0}{0} \\
\frac{0}{0}\end{array}$ & 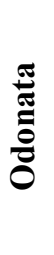 & & $\frac{\pi}{\frac{\pi}{20}}$ & $\frac{\pi}{\frac{\pi}{0}}$ & 矛 & $\frac{\pi}{\frac{\pi}{2}}$ & 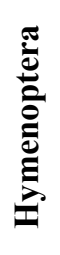 & 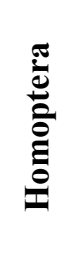 & 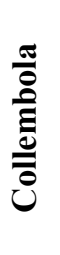 & $\begin{array}{l}\frac{\pi}{0} \\
\stackrel{0}{0} \\
\stackrel{0}{\circ}\end{array}$ \\
\hline \multirow{2}{*}{1} & Blue & 1,145 & 1,982 & - & 21 & 2,223 & 664 & 7 & 154 & 4 & 20 & 4 & - \\
\hline & Black & 1,703 & 1,592 & - & 10 & 1,280 & 372 & 8 & 58 & 10 & 58 & - & 1 \\
\hline \multirow{2}{*}{2} & Blue & 828 & 2,453 & 1 & 6 & 1,813 & 610 & 4 & 109 & 5 & 76 & 7 & - \\
\hline & Black & 551 & 1,830 & 2 & 51 & 1,629 & 1,025 & 8 & 154 & 6 & 38 & 15 & - \\
\hline \multirow{2}{*}{3} & Blue & 1,356 & 352 & 1 & 2 & 549 & 759 & 10 & 129 & 4 & 127 & - & - \\
\hline & Black & 3,675 & 2,131 & 1 & 7 & 5,576 & 597 & 6 & 163 & 13 & 422 & - & 6 \\
\hline \multirow{2}{*}{4} & Blue & 1,207 & 360 & - & 8 & 2,101 & 440 & 16 & 108 & - & 231 & - & 3 \\
\hline & Black & 430 & 115 & 1 & 4 & 1,313 & 415 & 5 & 183 & 4 & 66 & - & - \\
\hline
\end{tabular}

\section{Conclusions}

The blue light fluorescence tube had a wavelength from 405 to $630 \mathrm{~nm}$, giving many spectrums compared with the black light fluorescence tube with a wavelength of $630 \mathrm{~nm}$, which gave only a purple light. The black light trap was able to trap insects more than the blue light trap. However, when compared to insect order, purple light is suited to collect Hymenoptera while blue light is suited for Coleoptera and Hemiptera, following Henda et al. 1999 [41]. Lepidoptera does not have a specific light due to its responses to wavelength $340-460 \mathrm{~nm}$, a wavelength of blue and black light fluorescence tube [42].

Sampling point 3 had the highest species abundance and diversity of Trichoptera, especially on Hydropsychidae. Hydropsychid larva was a filter feeder. High turbulence flow and stable substrate suited them, while sampling point 2 had the lowest abundance and diversity. This sampling point was an open area that directly receives wind, which is not good for Trichoptera that cannot fly well. So, species abundance and diversity depend on their life cycle, habitat, and environment [43]. Cheumatopsyche schwendingeri, Potamyia euadne, Ecnomus obtusus, Ecnomus mammus, Ecnomus singkarakensis, Ecnomus alkmene, Ecnomus alkaios, Oecetis kodros, Setodes tejasvin, Setodes okyrrhoe, Psychomyia kalais, Paduniella sampati, Hydroptila gaya, Chimarra terramater were a dominant species in this reservoir while Cheumatopsyche copia, Potamyia alleni, Cheumatopsyche schwendingeri, Potamyia euadne, Potamyia phaidra, Ecnomus alkaios, Oecetis bengalica, Oecetis meghadouta, Oecetis kodros, Setodes argentiguttatus, $S$. sarapis, $S$. tejasvin, $S$. okyrrhoe, Leptocerus posticus, Psychomyia kalais, $P$. lak, Abaria guatila, Hydroptila sabit, Oxyethira bogambara, Ugandatrichia honga, Marilia sumatrana, Chimarra toga, C. chiangmaiensis, C. terramater and C. monorum were rare species.

An Individual number of insect's orders between lentic and lotic habitat did not significantly differ while it differed between the sampling point. In the lentic habitat, the reservoir bottom was fine sediment that suits a burrower insect. Sampling point 1 was near a forest, but sampling point 2 was an open area. It made sampling point 1 collected insect more than sampling point 2 . In the lotic habitat, the channel bottom of sampling point 3 had various materials near the reservoir's spillway. It suits Trichoptera and Ephemeroptera, which their larva requires high dissolved oxygen. At the same time, Diptera was abundant in sampling point 2 because there is a high deposit of debris, providing a perfect micro habitat for dipterans larva $[44,45]$.

Diversity indices showed that habitat type was more affected by insect abundance and diversity than light traps. Some insect orders such as Collembola and Isoptera and many species of Trichoptera were rather specific to microhabitat. Changing running water to standing water or standing water to running water may affect the existence of these insects. The seasonal study is necessary to answer which species 
can be used to indicate an environmental change in this reservoir and to understand the role of these insects in the ecosystem [46].

\section{Acknowledgements}

Thanks to the School of Science, the University of Phayao, Thailand for supporting the research and for letting us used the facilities. Special thanks also go out to the officer of the Mae Tum reservoir for supporting in the research area.

\section{References}

[1] TE Hienton. Summary of investigations of electric insect traps. Agricultural Research Service, U.S. Department of Agriculture, Maryland, 1974, p. 136.

[2] A Dethier. Use of light traps in insects surveys plant protection service technical bulletin 29. Thailand, 1963.

[3] P Chantaramongkol and H Malicky. Some Chimarra (Trichoptera: Philopotamidae) from Thailand (Studies on caddisflies from Thailand, No.2) Aquat. Insects 1989; 11, 223-40.

[4] H Malicky. Odontoceridae aus Thailand (Trichoptera) (studien über thailändische köcherfliegen, Nr.4). Opusc. Zool. Flumin. 1989; 36, 1-16.

[5] H Malicky. Some unusual caddisflies (Trichoptera) from Southeastern Asia (studies on caddisflies of Thailand, No.5). In: Proceedings of the $6^{\text {th }}$ International Symposium on Acoustic Wave Devices for Future Mobile Communication Systems, Chiba, Japan. 1989, p. 381-4.

[6] H Malicky and P Chantaramongkol. Beschreibung von neuen köcherfliegen (Trichoptera) aus Thailand and Burma) (Arbeiten über thailändische köcherfliegen Nr.6). Entomol. Ber. (Luzern) 1989; 22, 117-26.

[7] H Malicky and P Chantaramongkol. Neue köcherfliegen (Trichoptera) aus Thailand und angrenzenden ländern) (arbeiten über thailändische köcherfliegen Nr.11). Braueria (Lunz am See, Austria) 1992; 19, 13-23.

[8] H Malicky and P Chantaramongkol. Neue Trichoptern aus Thailand. Teil 1: Rhyacophilidae, hydrobiosidae, philopotamidae, polycentropodidae, ecnomidae, psychomyidae arctopsychidae, hydropsychidae (arbeit über thailändishe köcherfliegen Nr.12)1. Linzer Biol. Beitr. 1993; 25, 433-87.

[9] H Malicky and P Chantaramongkol. Neue trichoptern aus Thailand. Teil 2: Rhyacophilidae, philopotamidae, polycentropodi-dae, ecnomidae, psychomyidae, xiphocentronidae, helicopsychi dae, odontoceridae. (Arbeit über thailändishe köcherfliegen Nr.12) (fortsetzung). Linzer Biol. Beitr. 1993; 23, 1137-87.

[10] H Malicky and P Chantaramongkol. Neue lepidostomatidae aus Asien (arbeiten über thailändishe köcherfliegen Nr.14) (Insecta: Trichoptera: Lepidostomatidae). Ann. Naturhist Mus. Wien. 1994; 96, 349-68.

[11] H Malicky.Weitere neue köcherfliegen (Trichoptera) aus Asien. Braueria (Lunzam See, Austria). 1995; 22, 11-26.

[12] P Chantaramongkol and H Malicky. Drei neue asiatische hydromanicus (Trichoptera: Hydropsychidae) (arbeiten über thailändische köcherfliegen Nr. 17). Ent. Z. (Essen) 1995; 105, 92-9.

[13] H Malicky.Ein Beitrag zur Kenntnis asiatischer Arten der Gattungen Cheumatopsyche WALLENGREN 1891 und Potamyia BANKS (Trichoptera, Hydropsychidae)(zugleich 22. arbeit über thailändishe köcherfliegen). Linzer Biol. Beitr. 1997; 29, 1015-55.

[14] H Malicky. Ein beitrag zur kenntnis asiatischer macronematini (Trichoptera, hydropsychidae) (zugleich 24. arbeit über thailändishe köcherfliegen). Linzer Biol. Beitr. 1998; 30, 767-93.

[15] H Malicky. The net-spinning larva of the giant microcaddisfly, ugandatrichia spp. (tricoptera, hydroptilidae) (study No. 25 on caddisflies of Thailand). In: Proceedings of the $9^{\text {th }}$ International Symposium on Trichoptera, Chiang Mai University, Chiang Mai, Thailand. 1999, p. 205-16.

[16] H Malicky and P Chantaramongkol. A preliminary survey of the caddisflies (Trichoptera) of Thailand. study no. 26 on Caddisflies of Thailand. In: Proceedings of the $9^{\text {th }}$ International Symposium on Trichoptera, Chiang Mai University, Chiang Mai, Thailand. 1999, p. 205-16.

[17] H Malicky and P Chantaramongkol. Ein beitrag zur kenntnis asiatischer hydropsyche-arten (Trichoptera, hydropsychidae) (Zugleich Arbeit Nr.24. über thailändishe köcherfliegen). Linzer Biol. Beitr. 2000; 32, 791-860.

[18] H Malicky, P Chantaramongkol, S Cheunbarn and N Saengpradab. Einige neue köcherfliegen (Trichoptera) aus Thailand (Arbeit Nr. 32 über thailändische köcherfliegen). Braueria 2001; 28, 11-4. 
[19] H Malicky, P Chantaramongkol, P Chaibu, P Thamsenanupap and I Thani. (arbeit Nr.31 über thailändische Trichoptera). Braueria 2000; 27, 29-31.

[20] H Malicky. Ein beitrag zur kenntnis asiatischer arten der gattung diplectrona WESTWOOD 1840 (Trichoptera, hydropsychidae) 1 (gleichzeitig arbeit Nr.34 über thailändishe köcherfliegen). Linzer Biol. Beitr. 2002; 34, 1201-36.

[21] H Malicky, P Chantaramongkol, N Saengpradab, N Changthong, S Cheunbarn, P Luadee, T Prommi and S Sompong. Neue asiatische leptoceridae (Trichoptera) (zugleich arbeit Nr. 33 über thailändische köcherfliegen). Braueria 2002; 29, 15-30.

[22] H Malicky, P Chantaramongkol, N Saengpradab, P Chaibu, I Thani, N Changthong, S Cheunbarn, P Laudee, T Prommi and S Sompong. Neue asiatische leptoceridae (Trichoptera) (zugleich arbeit Nr.33. über thailändishe köcherfliegen). Braueria 2002; 29,15-30.

[23] FC de Moor, and VD Ivanov. Global diversity of caddisflies (Trichoptera: Insecta) in freshwater. Hydrobiologia 2007; 595, 393-407.

[24] P Chantaramongkol and H Malicky. Trichoptera from Doi Suthep-Pui national park, northern Thailand (studies on Trichoptera of Thailand No.15). In: Proceedings of the $8^{\text {th }}$ International Symposiumon Trichoptera, Ohio Biological Survey. 1997, p. 65-7.

[25] P Chantaramongkol, P McQuillan and S Promkutkaew. Analysis of Trichoptera adult seasonality from Huay Koo Kaow stream, Chiang Mai Zoo, Doi Suthep, Thailand. In: Proceedings of the $9^{\text {th }}$ International Symposium on Trichoptera, Chiang Mai, Thailand. 1999, p. 469-74.

[26] H Malicky. On some Rhyacophila from Doi Suthep mountain, northern Thailand (studies on caddisflies from Thailand, No.1) Trichop. Newsletter 1987; 14, 27-9.

[27] H Malicky and P Chantaramongkol. The altitudinal distribution of Trichoptera species in Mae Klang catchment on Doi Inthanon Northern Thailand: Stream zonation and cool and warm adapted groups (studies on caddisflies of Thailand No. 16). Rev. Hydrobiol. trop. 1993; 26, 279-91.

[28] D Thapanya, P Chantaramongkol and P Mcquillan. Trichoptera communities along an altitude transect on Himalayan-inlier and Himalayanoutlier mountains in Chiang Mai Province, Thailand. In: Proceedings of the $11^{\text {th }}$ International Symposium on Trichoptera, Kanagawa, Japan. 2005, p. 429-33.

[29] D Thapanya, P Bunlue and P Chantaramongkol. Adult caddisfly assemblages from upstream and downstream of the Mae Ngat Dam, Chiang Mai, northern Thailand. Biol. Inl. Wat. Suppl. 2013; 2, 151-6.

[30] P Suriyawonga, D Thapanya, EA Bergey, P Chantaramongkol. Check dams exacerbate the effects of high flow on aquatic insect communities in tropical stream of northern Thailand. ScienceAsia 2018; 44, 292-302.

[31] H Malicky. Atlas of Southeast Asian Trichoptera. Biology Department, Science Faculty, Chiang Mai University, 2010.

[32] JC Morse. Trichoptera world checklist, Available at: http://www.clemson.edu/cafls/ departments/ esps/ database/trichopt/index.htm, accessed November 2019.

[33] AE Maguran. Ecological Diversity and Its Measurement. Springer, Dordrecht, 1988, p. 94-5.

[34] CL Amick. Fluorescent Lamps. McGraw-Hill Book Company, New York, 1942, p. 16-8.

[35] WE Forsythe and EQ Adams. Fluorescent and other gaseous discharge lamps. Murray Hill Books, New York, 1948, p. 119-20.

[36] T Prommi, P Luadee and T Chareonviriyaphap. Biodiversity of adult Trichoptera and water quality variables in streams, Northern Thailand. APCBEE Proc. 2014; 10, 292-8.

[37] P Laudee and T Prommi. Biodiversity and distribution of Trichoptera species along the Tapee River, Surat Thani Province, southern Thailand. Zoosymposia 2011; 5, 279-87.

[38] FR Hauer and GA Lamberti. Methods in stream ecology. $2^{\text {nd }}$ ed. Elsevier Academic Press, China, 2000

[39] DD Williams and BW Feltmate. Aquatic insects. CAB International, 1992.

[40] D Dudgeon. Tropical Asian streams. Hong Kong University Press, Hong Kong, 1999, p. 356-412.

[41] $\mathrm{H}$ Nabli, WC Bailey and S Necibi. Beneficial insect attraction to light traps with different wavelengths. Biol. Control. 1999; 6, 185-8.

[42] F Castrejon and JC Rojas. Behavioral responses of larvae and adults of Estigmene acrea (lepidoptera: Arctiidae) to light of different wavelengths. Fla. Entomol. 2010; 93, 505-9.

[43] A Nuntakwang, P Chantaramongkol and GW Courtney. Biodiversity and biogeographic connections of Trichoptera from mountain streams of Northern Thailand. In: Proceedings of the $12^{\text {th }}$ International Symposium on Trichoptera, Mexico City, Mexico. 2006, p. 259-62.

[44] T Prommi, and P Chantaramongkol. A preliminary survey of adult Trichoptera communities in Thongphaphum Didrtict, Kanchanaburi Province, Thailand. In: Proceedings of the $11^{\text {th }}$ International Symposium on Trichoptera, Tokai University Press, Kanagawa, Japan. 2003, p. 355-61. 
[45] T Prommi, K Seetapan and P Thamsenanupap. Diversity and seasonality of caddisflies (insecta: Trichoptera) at Champathong waterfall, northern Thailand. SDU Res. J. 2012; 5, 125-37.

[46] JC Morse, PB Frandsen, G Wolfram and JA Thomas. Diversity and ecosystem services of Trichoptera. Insects 2019; 10, 125. 